JOURNAL OF NURSING PRACTICE AND EDUCATION

VOL. 01 No. 02, JUNI 2021

DOI: $10.34305 /$ jnpe.v1i2.272
Ciptaan disebarluaskan di bawah Lisensi

Creative CommonsAtribusi-NonKomersialBerbagiSerupa 4.0

\title{
HUBUNGAN POLA AKTIVITAS FISIK DAN RIWAYAT PENYAKIT DENGAN KADAR HEMOGLOBIN PADA REMAJA PUTRI DI SMAN 1 LURAGUNG KECAMATAN LURAGUNG KABUPATEN KUNINGAN
}

\author{
Nita Ike Dwi Kurniasih, Anggit Kartikasari, Russiska, Nurlelasari \\ STIKes Kuningan \\ nitaikedk@gmail.com
}

\begin{abstract}
Abstrak
Golongan yang termasuk rawan menderita anemia adalah remaja putri. Kejadian anemia pada remaja putri di kabupaten Kuningan termasuk cukup tinggi yaitu 27\%. Seseorang dikatakan mengalami anemia jika kadar hemoglobin $(\mathrm{Hb})$ dalam darah rendah. Kadar hemoglobin seseorang bisa menurun diantaranya disebabkan karena pola aktivitas fisik dan riwayat penyakit. Tujuan penelitian ini untuk mengetahui hubungan pola kativitas fisik dan riwayat penyakit dengan kadar hemoglobin pada remaja di SMN 1 Luragung. Metode penelitian menggunakan penelitian analitik dengan rangcangan survey cros secttional. Jumlah populasi 215 responden, teknik pengambilan sampel menggunakan purposive sampling didapatkan sampel 66 responden yang memenuhi kriteria. Analisis data univariat dan bivariat, analisis bivariat menggunkan Chi Square. Hasil penelitian dari 66 responden didapatkan sebagian besar remaja putri memiliki pola aktivitas baik 51,5 , tidak memiliki riwayat penyakit $68,2 \%$, tidak anemia $73.3 \%$, Hasil uji analitik pada aktivitas fisik dengan kadar hemoglobin $\rho_{\text {value }}=0,244$ menunjukan tidak ada hubungan, dan pada riwayat penyakit dengan kadar hemoglobin $\rho_{\text {value }}$ $=0,532$ menunjukan tidak ada hubungan. Berdasarkan penelitian ini menunjukan tidak ada hubungan pola aktivitas fisik dan riwayat penyakit dengan kadar hemoglobin. Bagi Kepala Sekolah SMA Negeri 1 Luragung diharapkan dapat bekerja sama dengan UPTD Puskemas setempat dengan penyuluhan gizi dan nutrisi untuk upaya penanggulangan anemia pada remaja.
\end{abstract}

Kata kunci $\quad$ : Akivitas Fisik, Riwayat Penyakit, Kadar Hemoglobin

\section{Pendahuluan}

Masa remaja dimulai dari usia 9-18 tahun dimana masa yang menghubungkan masa kanak-kanak sampai dewasa. Masamasa remaja adalah waktu yang penting karena merupakan saat perubahan psikologis 
JouRnal of NURSING PRACTICE AND EDUCATION VOL. 01 NO. 02, JUNI 2021

DOI: $10.34305 /$ jnpe.v1i2.272

dan fisik. Golongan yang termasuk rawan menderita anemia adalah remaja putri, keadan ini bisa terjadi disebabkan masa remaja termasuk masa-masa saat terjadinya pertumbuhan dan setiap bulan remaja putri mengalami menstruasi yang menyebabkan kehilangan zat besi (Arisman, 2009). Seseorang dikatakan mengalami anemia jika kadar hemoglobin $(\mathrm{Hb})$ dalam darah rendah (Chibriyah \& Anita, 2017). Menurut World Health Organization WHO (2013) diperkirakan $30 \%$ penduduk dunia menderita anemia terutama di negara berkembang. Anemia yang merupakan salah satu masalah kesehatan di dunia ini banyak terjadi pada remaja dan ibu hamil. Kejadian Anemia sampai saat ini masih cukup tinggipada remaja putri. Menurut Lubis (2013), anemia sangat berpengaruh terhadap kesehatan reproduksi terutama pada wanita. Bukan hanya pola aktivitas saja yang berpengaruh pada penderita anemia defisiensi zat besi tetapi bisa dari faktor penyakit infeksi. Penyebab anemia defisiensi zat besi pada remaja diantaranya yaitu pengetahuan yangkurang mengenai anemia, kebiasaan minum kopi dan teh setelah makan (Chauhan et al., 2016). Faktor terpenting yang berkontribusi terhadap anemia defisiensi zat besi pada remaja yaitu kekurangan zat besi, status sosio ekonomi
Ciptaan disebarluaskan di bawah Lisensi Creative CommonsAtribusi-NonKomersialBerbagiSerupa 4.0

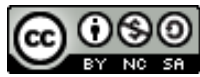

rendah, obesitas, aktivitas fisik intens, dandietzat besi, riwayat menstruasi kehilangan darah $>80 \mathrm{ml} /$ bulan.

Hasil studi pendahuluan di SMAN 1 Luragung Kecematan Luragung Kabupaten Kuningan dari 12 orang remaja putri tedapat 7 orang yang mengalami anemia. Berdasarkan uraian diatas peneliti tertarik untuk melakukan penelitian "Hubungan Pola Aktivitas Fisik Dan Riwayat Penyakit dengan Kadar Hemoglobin Pada Remaja Putri di SMAN 1 Luragung”.

\section{Metode}

Penelitian ini merupakan penelitian kuantitatif dengan desain crossectional. Populasi dalam penelitian ini adalah remaja putri kelas XI yang berada di SMAN 1 Luragung. Teknik sampel menggunakan purposive sampling sebanyak 66 siswi. Instrumen yang digunakan berupa kuesioner aktivitas fisik berdasarkan Physical Activity Questionaire (PAQ-C) dan lembar informed consent sebagai lembar observasi. Analisis data yang digunakan yaitu univariat, bivariat dengan menggunakan chi square.

\section{Hasil}

Berikut ini disajikan tabel distribusi frekuensi yang menggambarkan Hubungan Pola Aktivitas Fisik Dan Riwayat Penyakit 
JOURNAL OF NURSING PRACTICE AND EDUCATION VOL. 01 NO. 02, JUNI 2021

DOI: $10.34305 /$ jnpe.v1i2.272
Ciptaan disebarluaskan di bawah Lisensi

dengan Kadar Hemoglobin Pada Remaja

Putri di SMAN 1 Luragung.

Tabel 1 Gambaran Distribusi Frekuensi Pola Aktivitas Fisik, Riwayat Penyakit, Kadar Hemoglobin Pada Remaja Putri Di SMAN 1 Luragung

\begin{tabular}{|c|c|c|c|}
\hline No & Vaiabel & Frekuensi (f) & Persentase $(\%)$ \\
\hline \multirow[t]{4}{*}{1} & Pola Aktivitas Fisik & & \\
\hline & Baik & 34 & 51,5 \\
\hline & Kurang & 32 & 48,5 \\
\hline & Jumlah & 66 & 100 \\
\hline \multirow[t]{4}{*}{2} & Riwayat Penyakit & & \\
\hline & Memiliki & 21 & 41,8 \\
\hline & Tidak Memiliki & 45 & 68,2 \\
\hline & Jumlah & 66 & 100 \\
\hline \multirow[t]{4}{*}{3} & Kadar Hemoglobin & & \\
\hline & Anemia & 15 & 22,7 \\
\hline & Tidak Anemia & 51 & 73,3 \\
\hline & Jumlah & 66 & 100 \\
\hline
\end{tabular}

Tabel 2 Hubungan Pola Aktivitas Fisik Dengan Kadar Hemoglobin Di SMAN 1 Luragung

\begin{tabular}{|c|c|c|c|c|c|c|c|c|}
\hline \multirow{3}{*}{ No } & \multirow{3}{*}{ Pola Aktivitas fisik } & \multicolumn{4}{|c|}{ Kadar Hemoglobin } & \multirow{2}{*}{\multicolumn{2}{|c|}{ Jumlah }} & \multirow{3}{*}{$\rho_{\text {value }}$} \\
\hline & & \multicolumn{2}{|c|}{ Anemia } & \multicolumn{2}{|c|}{$\begin{array}{c}\text { Tidak } \\
\text { Anemia }\end{array}$} & & & \\
\hline & & $\mathbf{N}$ & $\%$ & $\mathbf{N}$ & $\%$ & $\mathbf{N}$ & $\%$ & \\
\hline 1 & Baik & 10 & 29.4 & 24 & 70.6 & 34 & 100 & \\
\hline 2 & Kurang Baik & 5 & 15.6 & 27 & 84.4 & 32 & 100 & \\
\hline
\end{tabular}

Tabel 3 Hubungan Pola Aktivitas Fisik Dengan Kadar Hemoglobin Di SMAN 1 Luragung

\begin{tabular}{|c|c|c|c|c|c|c|c|c|}
\hline \multirow{3}{*}{ No } & \multirow{3}{*}{ Riwayat Penyakit } & \multicolumn{4}{|c|}{ Kadar Hemoglobin } & \multirow{2}{*}{\multicolumn{2}{|c|}{ Jumlah }} & \multirow{3}{*}{$\rho_{\text {value }}$} \\
\hline & & \multicolumn{2}{|c|}{ Anemia } & \multicolumn{2}{|c|}{$\begin{array}{c}\text { Tidak } \\
\text { Anemia }\end{array}$} & & & \\
\hline & & $\mathbf{N}$ & $\%$ & $\mathbf{N}$ & $\%$ & $\mathbf{N}$ & $\%$ & \\
\hline 1 & Memiliki & 6 & 28.6 & 15 & 71.4 & 21 & 100 & \\
\hline 2 & Tidak Memiliki & 9 & 20.0 & 36 & 80.0 & 45 & 100 & שנת, \\
\hline
\end{tabular}

\section{Pembahasan}

Berdasarkan hasilpenelitian dari 66 responden pada pola aktivitas fisik baik sebanyak 34 orang $(51.5 \%)$. Setiap gerakan tubuh yang meningkatkan pengeluaran dan pembakaran energi disebut pola aktivitas fisik. Segala aktivitas fisik dikatakan baik apabila seseorang melakukan latihan fisik atau olah raga selama 30 menit setiap hari 
JouRnal of NURSING PRACTICE AND EDUCATION VOL. 01 NO. 02, JUNI 2021

DOI: $10.34305 /$ jnpe.v1i2.272

atau minimal 3-5 hari dalam seminggu. Aktivitas fisik dikategorikan berat, apabila aktivitas fisik yang dilakukan selama 3 hari atau lebih dan juga bisa dilakukan kombinasi berjalan selama 7 hari atau lebihdengan intensitas keras. Aktivitas fisik seang yaitu aktivitas yang dilakukan minimal 20 menit selama 3 hari/lebih atau selama minimal 5 hari atau berjalan minimal 30 menit setiap haridengan intensitas kuat. Kategori terendah dalam aktivitas fisik yaitu aktivitas fisik ringan. Aktivitas ringan merupakan segala kegiatan yang tidak memenuhi kategori aktivitas sedang maupun beratdan ketika seseorang tidak melakukan segala jenis kegiatan apapun (Sabrina, 2012).

Pola aktivitas fisik pada pada remaja putri di SMAN 1 Luragung sebagian besar memiliki pola ativitas fisik baik dan terdapat 32 responden yang mengalami aktivitas fisik kurang.Aktivitas fisik yang sifatnya berat merupakan aktifitas yang dapat mempengaruhi kadar hemoglobin karena terjadi hemolisis dalam darah sehingga proses transfortasi oksigen dalam darah tergangggu dan menyebakan kadar hemoglobin rendah.

Hasil penelitian menunjukan dari 66 responden terdapat sebanyak 45 orang $(68.2 \%)$ yang tidak memiliki riwayat penyakit. Kebutuhan tubuh yang meningkat
Ciptaan disebarluaskan di bawah Lisensi Creative CommonsAtribusi-NonKomersialBerbagiSerupa 4.0 akibat mengidap penyakit kronis dan infeksi parasit (cacing), hemoroid (ambien) dan perdarahan merupakan penyebab yang dapat mempengaruhi kadar $\mathrm{Hb}$ dalam darah (Rizkiawati, 2012).

Tubuh seseorang akan mudah terkena infeksi ketika mengalami anemia, hal ini terjadi karena anemia dapat menurunkan daya tahan tubuh yang menyebabkan seseorang akan mudah terinfeksi. Hal ini menunjukan bahwa infeksi adalah faktor penting dalam menimbulkan terjadinya anemia dan anemia terjadi akibat dari peradangan dan kebutuhab asupan makanan yang tidak cukup kandungan zat besi. Kehilangan darah akibat schistosomiasis, infestasi cacing, dan trauma dapat menyebabkan defisiensi zat besi dan anemia. Angka kesakitan akibat penyakit infeksi meningkat pada populasi defisiensi besi akibat efek yang merugikan terhadap sistem imun. Malaria karena hemolisis dan beberapa infeksi parasit seperti cacing, trichuriasis, amoebiasis, dan schistosomiasis menyebabkan kehilangan darah secara langsung dan kehilangan darah tersebut mengakibatkan defisiensi besi (Arumsari, 2008).

Riwayat penyakit pada remja putri di SMAN 1 Luragung sebagian besar tidak memilki riwayat penyakit di lihat dari 
JouRnal of NURSING PRACTICE AND EDUCATION VOL. 01 NO. 02, JUNI 2021

DOI: $10.34305 /$ jnpe.v1i2.272

kusioner bahwa aktivitas fisik remaja putri dikategorikan baik, yang berarti bahwa dalam tubuh para remaja tersebut sistem kerja tubuhnya baik jadi tidak ada metabolisme dalam tubuh yang terganggu. Sebab adanya penyakit dikarenakan adanya gangguan pada salah satu fungsi tubuh yang terganggu.

Berdasarkan hasil penelitian dari 66 responden pada kadar hemoglobin yang tidak anemia sebanyak 51 orang $(73.3 \%)$ dan yang anemia sebanyak 15 (22.7\%). Sebagian besar mengalami anemia, penyebab terjadinya anemia pada remaja putri memang dipicu berbagai faktor diantaranya kehilangan darah pada saat mestruasi setiap bulannya dan pola makan sehari-hari. Hal ini menujukan adanya masalah yang harus diwaspadai oleh tenaga kesehatan karena tidak menutup kemungkinan dari remaja putri yang sudah terdekteksi mengalami anemia akan mengakibtkan remaja tersebut mudah lelah dan tidak berkonsentrasi dalam pelajaran. Kadar Hemoglobin yang normal, membuat darah dapat menjalankan fungsinya dengan baik. Sebagai sarana transportasi untuk membawa oksigen, jika jumlah Hemoglobin kurang dari normal maka transportasi oksigen ke seluruh tubuh akan terganggu (Proverawati, 2011).
Ciptaan disebarluaskan di bawah Lisensi Creative CommonsAtribusi-NonKomersialBerbagiSerupa 4.0

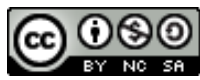

Berdasakan hasil penelitian diperoleh hasil dari 66 responden sebanyak $34(51.5 \%)$ orang termasuk kelompok pola aktivitas baik yang tidak mengalami anemia terdapat $24(70.6 \%)$ orang. Sedangkan pola aktivitas fisik kurang terdapat 32 (48.5\%) orang yang tidak mengalami anemia 27 (84.4\%) orang. Berdasarkan hasil Uji Chi Square pada penelitian mengenai hubungan pola kativitas fisik dengan kadar hemoglobin diperoleh $\rho_{\text {value }}=0,244$, maka $\rho_{\text {value }}>0,05$. Hal ini menunjukan bahwa tidak ada hubungan antara pola aktivitas fisik dengan kadar hemoglobin. Aktivitas fisik yang dilakukan oleh remaja putri di SMAN 1 Luragung tidak berlebihan yang menyebabkan anemia. Hal ini terjadi karena aktivitas yang tidak berlebihan tidak akan mengakibatkan dinding sel darah merah menjadi rusak dan tidak mengakibatkan energi dalam tubuh seseorang berukurang sehingga zat gizi yang dikonsumsi masuk dandiproses dengan baik kedalam tubuh sebagai upaya untuk pembentukan hemoglobin supaya tidak terjadi penurunan kadar hemoglobin dalam darah seseorang.

Hasil penelitian ini sejalan dengan penelitian Rizkiwati (2012)menunjukan nilai $\mathrm{p}=0,574(\mathrm{p}>0,05)$ untuk korelasi aktivitas fisik dengan kadar $\mathrm{Hb}$ darah yang artinya tidak ada hubungan antara aktivitas 
JouRnal of NURSING PRACTICE AND EDUCATION VOL. 01 NO. 02, JUNI 2021

DOI: $10.34305 /$ jnpe.v1i2.272

fisik dengan kadar $\mathrm{Hb}$ pada tukang becak di Pasar Mranggen, Demak (Rizkiawati, 2012). Hasil penelitian tersebut didukung oleh teori yang dikemukakan oleh Chibryah dan Anita (2017) kadar hemoglobin seseorang dalam darah sangat dipengaruhi oleh aktivitas fisik yang dilakukan oleh seseorang. Kadar hemoglobin akan naikketika seseorang melakukan olahraga secara rutin. Keadaan seperti ini bisa terjadi disebabkan ketika sesorang melakukan aktivitas makajaringan atau sel akan lebih banyak membutuhkan O2. Selain itu keadaan yang dialami seseorang beragam ada yang memunjukan hasil kadar $\mathrm{Hb}$ normal namun memiliki kesegaran jasmani yang kurang, keadaan seperti ini disebabkan adanya faktor lain selain kadar $\mathrm{Hb}$ yang menentukan kesehatan jasmani seseorang (Chibriyah \& Anita, 2017).

Aktivitas fisik dengan kategori berat menunjukan segala kegiatan yang dapat mempengaruhi kadar hemoglobin. Selain itu aktivitas fisik dengan kategori berat dan intensitas latihan yang kuat dapat mengakibatkan terjadinya hematuria, hemolisis dan perdarahan pada gastroinstestinal. Hal ini yang dapat mempengaruhi kadar zat besi dalam tubuh seseorang. Selain itu hematuria dapat terjadi karena adanya trauma pada glomerulus,
Ciptaan disebarluaskan di bawah Lisensi Creative CommonsAtribusi-NonKomersialBerbagiSerupa 4.0 sehingga menyebabkan aliran darah pada ginjal menurun dan menyebabkan peningkatan laju filtrasi glomerulus. Aktivitas fisik yang berat akan mengakibatkan kontraksi otot yang kuat yang berlanjut terjadinya kompresi pembuluh darah sehingga seseorang akan mengalami hemolisis. Hemolisis dapat menyebabkan kehilangan zat besi akibat dari penghancuran membrane sel darah merah yang akan mempengaruhi kadar $\mathrm{Hb}$ dalam darah (Proverawati, 2011).

Berdasarkan hasil penelitian diperoleh dari 66 responden sebanyak $(68,2 \%)$ termasuk kelompok tidak memiliki riwayat penyakit yang tidak mengalami anemia terdapat 36 orang (80.0\%). Sedangkan yang memiliki riwayat penyakit sebanyak 21 orang $(31.8 \%)$ yang tidak mengalami anemia 15 orang (71.4\%). Berdasarkan hasil Uji Chi Square pada penelitian tentang hubungan riwayat penyakit dengan kadar hemoglobin diperoleh $\rho_{\text {value }}=0,532$, maka $\rho_{\text {value }}>0,05$. Hal ini menunjukan bahwa tidak ada hubungan antara riwayat penyakit dengan kadar hemoglobin. Penelitian ini sejalan dengan penelitian Furuhita K.A (2012) Hasil uji korelasi antara kejadian anemia dengan penyakit infeksi diperoleh nilai $\mathrm{p}>0,05$ yang menunjukan tidak ada 
JouRnal of NURSING PRACTICE AND EDUCATION VOL. 01 NO. 02, JUNI 2021

DOI: $10.34305 /$ jnpe.v1i2.272

hubungan riwayat penyakit dengan kadar hemoglobin. Kemudian penelitian ini juga sejalan peneitian Rizkiawati (2012) $(\mathrm{p}=0,785)$, tidak ada hubungan antara riwayat penyakit dengan kadar Hemoglobin darah (Rizkiawati, 2012).

$$
\text { Riwayat penyakit tidak }
$$

mempengaruhi terjadi anemia dikarenakan responden sebagian besar tidak memiliki riwayat penyakit seperti demam disertai menggigil, seperti penyakit malaria dan penyakit tubercullosis (TBC). Penyakit infeksi yang menyerang tubuh, seperti malaria juga mempunyai komponen otoimun dalam merusak dan menghancurkan tubuh manusia. Sel-sel darah merah terinfeksi oleh parasit malaria tentu saja akan pecah pada saat parasit tersebut matang dan keluar dalam jumlah banyak. Akan tetapi, pada infeksi kronis, anemia tetap terjadi dalam jumlah yang tidak sebanding besarnya (Sadikin, 2011).

\section{Kesimpulan}

Berdasarkan hasil penelitian hubungan pola kativitas fisik dan riwayat penyakit dengan kadar hemoglobin pada remaja putri di SMAN 1 Luragung, maka berdasarkan uji statistik dan analisis variabel disimpulkandari 66 responden didapatkan sebagian besar remaja putri memiliki pola
Ciptaan disebarluaskan di bawah Lisensi Creative CommonsAtribusi-NonKomersialBerbagiSerupa 4.0 aktivitas baik 51,5, tidak memiliki riwayat penyakit $68,2 \%$, tidak anemia $73.3 \%$, Hasil uji analitik pada aktivitasfisik dengan kadar hemoglobin $\rho_{\text {value }}=0,244$ menunjukan tidak ada hubungan,dan pada riwayat penyakit dengan kadar hemoglobin $\rho_{\text {value }}=0,532$ menunjukan tidak ada hubungan. Berdasarkan penelitian ini menunjukan tidak ada hubungan pola aktivitas fisik dan riwayat penyakit dengan kadar hemoglobin. Bagi Kepala Sekolah SMA Negeri 1 Luragung diharapkan dapat bekerja sama dengan UPTD Puskemas setempat dengan penyuluhan gizi dan nutrisi untuk upaya penanggulangan anemia pada remaja.

\section{Daftar Pustaka}

Arisman, M. (2009). Buku Ajar Ilmu Gizi dalam Daur Kehidupan. EGC.

Arumsari. (2008). Faktor Resiko Anemia Pada Remaja Putri Peserta Program Pencegahan dan Penanggulangan Anemia Gizi Besi (PPAGB) di Kota Bekasi [Skripsi]. Fakultas Pertanian, Institut Pertanian Bogor.

Chauhan, U., Sandeep, G., \& Dahake, P. (2016). Correlation Between Iron Deficiency Anemia And Cognitive Achievement In School Aged Children. Annals Of International Medical And Dental Research, 2(4). https://doi.org/10.21276/aimdr.

Chibriyah, R., \& Anita, D. C. (2017). Hubungan Pola Makan Dan Aktivitas Fisik Terhadap Kadar Hemoglobin

E-ISSN 2775-0663| 89 
JOURNAL OF NURSING PRACTICE AND EDUCATION

VOL. 01 NO. 02, JUNI 2021

DOI: $\underline{10.34305 / j n p e . v 1 i 2.272}$

Santriwati Pondok Pesantren AlMunawwir Krapyak Bantul. Universitas 'Aisyiyah Yogyakarta.

Furuhita K.A. (2012). Hubungan Antara Kejadian Anemia Dengan Aktivitas Fisik Dan Terjadinya Penyakit Infeksi Pada Siswi Kelas Xi Sma Negeri 2 Sukoharjo. Universitas Muhammadiyah Surakarta.

Lubis, N. . (2013). Psikologi Kespro wanita dan perkembangannya. kencana prenada media group.

Proverawati, A. (2011). Anemia dan Anemia Kehamilan. Nuha Medika.

Rizkiawati, A. (2012). Faktor-Faktor Yang
Ciptaan disebarluaskan di bawah Lisensi Creative CommonsAtribusi-NonKomersialBerbagiSerupa 4.0

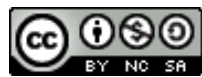
Berhubungan
Dengan
Kadar Hemoglobin $(\mathrm{Hb})$ Dalam Darah Pada Tukang Becak di Pasar Mranggen Demak. Jurnal Kesehatan Masyarakat, 2(1).

Sabrina. (2012). Faktor-Faktor Yang Berhubungan Dengan Kejadian Anemia Pada Mahasiswi Tingkat I Di Stikes Medika Nurul Islam Sigli Kabupaten Pidie. Sekolah Tinggi Ilmu Kesehatan U'budiyah Program Studi Diploma Iv Kebidanan Banda Aceh.

Sadikin. (2011). Biokimia Darah. Widya Medika.

WHO. (2013). Adolencent Health Information System. 